\title{
[9]
}

\section{Education, the Great Escape}

While state power and the national economy affect indirectly even intimate family and community institutions in Taiwan, some institutions and patterns of life are very directly shaped by the forces "out in society." Education is one of the strongest of these forces, making itself felt in every family in Taiwan. Chinese people take education very seriously; it has for centuries offered an escape from poverty and manual work in a preindustrial society where nearly everyone but a tiny class of official academic degree-holders farmed or labored for a living.

Learning is a sign of wealth, ease and security, and in the past only those with these advantages could afford to be learned. Traditional education stressed literacy in a difficult written language, an understanding of early forms of Chinese (comparable to learning the English of Chaucer or Beowulf), and familiarity with a body of classical texts whose relevance to practical daily matters was extremely limited. The learned were expected to use these language skills creatively, writing poetry as a pastime or at least inscribing documents, calling cards, and gift messages with the graceful calligraphy that indicates self-cultivation.

These traditions were taught to boys in the last century mostly in private academies or by home tutors. The Japanese initiated more modern schooling that retained many traditional elements while also incorporating parts of the Western curriculum. Education was far from universal even for the elementary-school population for whom it was primarily intended, but it was, surprisingly, coeducational. By the twenties, when Mr. Kho and Mrs. Lim (this chapter) were beginning their schooling, Taiwanese children could train as schoolteachers, technicians, and doctors. To succeed meant competition in the Japanese language with more and generally better- 


\section{Chinese Working-Class Lives}

trained Japanese children (see Tsurumi 1977). It is no wonder that many children, like Guo A Gui (Chapter 5), found their lessons too much trouble to pursue.

The Nationalists built on and expanded the Japanese system using retrained Taiwanese and Mandarin-speaking Mainlander refugees as teachers. Over the years, higher education based on Japanese beginnings and transplanted colleges from the mainland greatly increased the scope of occupational aspiration as well as Taiwan's industrial research capacity. In the fifties, the Nationalists pressured even skeptical rural folk to send all children to elementary school (Diamond 1969:77-79), apparently both because government officials shared the Chinese respect for learning, and because schooling seemed the most direct way to return the Japanized population to Chinese cultural orthodoxy and Nationalist sympathies. By 1970 , demanding sixth-year exams that filtered many elementary graduates out of the system were abandoned so that many more children at least began junior high school. Substantial tuition fees for middle schools continued in force for another decade, and they are still required of senior high students, a factor that discourages many poorer families from maintaining their children in high school.

Very early in my first stay in Taiwan, I passed a large, grim building with barred windows, out of which peered the wistful faces of a group of adolescent boys. Their heads were shaved nearly bald, and they wore plain khaki uniforms with numbers on the pockets.

"A juvenile prison," I thought, "and what a big one!" When I reached the entrance to the building, however, I realized my mistake. It was a senior high school-and, as I later learned, one of the best on the island. I soon came to take for granted the military-looking adolescents-boys in khaki, girls in various baggy skirt and blouse combinations of dark green, navy, khaki, and white. Until the last year of senior high, girls wore their hair cut straight off from earlobe to earlobe, and held away from the face with plain bobby pins. Younger children in elementary school wore similar uniforms topped off with bright yellow caps, so they would be easier to spot in traffic.

These outfits-cheap, practical, and reminiscent of the military uniforms then ubiquitous in Taiwan, summed up an important attitude toward education. Learning is hard, important work, a child's job in the same sense that carrying bricks or making noodles may be an adult's job: serious and, in a sense, official business.

Education takes the child, at the age of seven or so (the schools use Western birthdays to calculate age for this purpose), "out into society" under the direct influence of the state. The state requires universal schooling so that the young will grow up as disciplined, literate, and skilled 
workers in society, and as citizens who have been well instructed in the Nationalists' ideals and goals, including defense of the island and eventual reconquest of the mainland. Schools are not seen primarily as places for children to explore their capacities or develop socially (although these things also happen), but as training grounds for hard-working and loyal adults. Girls and boys should not distract each other when they reach puberty, so the separate girls' and boys' junior and senior high schools enforce an intentionally ugly, plain style of dress and grooming. Physical toughening is part of the school regime, through exercise, military drills, and drafty, unheated classrooms. Girls and the younger boys, who wear shorts, especially complain of the cold after sitting still for hours on raw winter days.

The style of learning in these schools also emphasizes discipline. The complex forms of the written Chinese characters that all children must learn bear only a limited relationship to the way they are pronounced, so learning each character demands a separate act of rote memorization. Children learn about two thousand characters in the six years of elementary school, and another four or five thousand by the end of senior high. After that, the high school graduate only occasionally needs to check a dictionary to read a newspaper, though a student studying college subjects must acquire a large new specialist's vocabulary, just as American college students do. Little children, just beginning this task, are usually assigned to write and review characters dozens of times as part of an evening's homework. At the same time, they learn to proportion each character within the conventions that make Chinese script an art form as well as a means of communication. English is taught in middle schools, and many college textbooks must be read in that language, adding to the burden of study. Coaching by an educated mother with plenty of time to spare helps enormously in keeping young children up to the mark (Diamond 1973).

Other subjects, too, stress the memorization of facts and, in vocational schools, of such specialized skills as calculating on an abacus or operating a massive Chinese typewriter - with keyboards of hundreds of keys. Chinese history and literature are naturally stressed, as are mathematics and science.

In place of the United States-oriented social studies and civics lessons American teenagers receive, Taiwan's young people study Chinese history from the Nationalist point of view and the political writings of Sun Yat-sen, the "father of the nation," who became its first president in 1911. Every school day begins with bowing to Sun's portrait, which hangs at the front of all classrooms. In political-study class, current Nationalist party materials are also discussed, sometimes under the leadership of one of the party 


\section{Chinese Working-Class Lives}

cadres assigned to maintain political orthodoxy in each school. These classes are important. If a child expresses unorthodox ideas on political subjects, the views and loyalty of her family may be investigated by the party or even the dreaded Garrison Command-the island's semisecret headquarters of martial law. Young people quickly learn to give the required responses on sensitive subjects, to show enough patriotism and to avoid conspicuousness. Some young people-in my experience, usually Mainlanders whose parents are strongly committed to the Nationalist government-are genuinely inspired by these sessions; most students find political study boring; children of convicted political criminals, I have heard, find them absolutely terrifying.

The discomfort, discipline, and hard work of education are not simply imposed by the state and accepted unwillingly by the students. Many Chinese schoolchildren take their "job" seriously and work hard, although the life histories also reveal many examples of children who found schooling too boring, too difficult, or too expensive to continue. Those who struggle to succeed at school do so because society, their families, and a long tradition of Chinese respect for education urge them on, but they also do it because their educational goals are clear and, for many, attainable. Education is the ladder of success, the path to riches, the great escape from manual work.

High-paying, high-status jobs in government and business require educational credentials from their applicants. Although graduating from college does not guarantee anyone such a job, not doing so dooms the attempt to rise to these positions. Entry into college is likely only for students who have climbed the educational ladder astutely, doing well at every level. A career as an engineer or business executive must begin almost in infancy.

Children take their first step toward success when they learn to speak. A child from Mandarin-speaking households and neighborhoods, growing up with the "national language," will enter the Mandarin-speaking school system more easily than one who speaks only Taiwanese. These days, assisted by many hours of Mandarin-language television programing, even Taiwanese children learn quickly in school from their Mandarin-speaking teachers. Until the mid-sixties, however, this was not so; Taiwanese, Hakka, and Aboriginal children began school with a pronounced language handicap. These days, education-conscious parents may decide to speak only Mandarin to their children, whatever their own first language is, while some even teach their children a little English, as well. This situation parallels perfectly the pattern of language use under the Japanese, when that language was required for academic success. As the following life history records, Mrs. Lim's unusual educational achievements owed much 
to her parent's coaching in Japanese, and she raised her own children to speak Mandarin as well as Taiwanese.

Families can also help their children do well scholastically by sending them to the best schools they can afford. Taibei has better schools than those in smaller cities, which in turn outperform rural ones. But even in Taibei, some elementary schools have higher academic traditions than others. An ambitious parent will reregister a child's residence with relatives who live in a good school district. This may mean a long commute on crowded buses, or the child may actually leave her rural home to live with urban relatives. Similar reshufflings may occur when the child moves up to junior high school; these, too, have differing standards.

At the end of junior high, students take exams that allocate them to variously ranked academic or vocational high schools. This is a critical sorting, for once tracked out of the relatively few schools that lead to college, it is nearly impossible to attain higher education. The few best girls' and boys' senior high schools in the major cities produce the majority of the students who are properly prepared to take the all-important college entrance examinations. Students may take these exams over again for several years if they fail, as Miss Ong's husband did. Based on their exam scores, high-school graduates are assigned to universities and to the academic areas they will study.

Young people take the college entrance exams for the main universities in an atmosphere of great solemnity and extreme anxiety. The candidates are sealed into the testing rooms with officially stamped strips of paper pasted across the doors, and great care is taken to prevent cheating or breaches of the anonymity under which the papers will be graded to ensure fairness. Families often escort their children to the examination and wait, anxiously burning incense and picnicking on the campus lawns, until they emerge from the ordeal. Weeks later, when exam results are posted, the campuses are jammed with young people searching the lists with carefully controlled faces.

For most people it is extremely difficult to get government permission to attend undergraduate school outside of Taiwan, and men cannot obtain it until they have completed military training. In the seventies and eighties, however, rich families have obtained citizenship either in the United States or in countries such as Costa Rica so they may send their children to American preparatory schools and universities - and so that they will have a refuge for themselves and their capital should Taiwan be taken over by the People's Republic.

For a very few students, beyond receiving a bachelor's degree from a Taiwan university lies graduate school at home or abroad. Many graduates 


\section{Chinese Working-Class Lives}

come each year to American universities to pursue advanced degrees. Since this pattern began in the fifties, over $\mathbf{9 0}$ percent of Taiwan graduate students have remained in the United States as engineers, chemists, and other professionals. After becoming permanent residents, many Mainlanders bring over their parents and other relatives. Taiwanese, initially disadvantaged by language and subtle discrimination, were once less likely to go abroad for advanced study and less likely to remain there, but this has changed. Wealthy Taiwanese are now as anxious about the future of the island as Mainlanders, and they are nearly as willing to emigrate.

Most young Taiwanese, of course, do not get American Ph.D.'s and leave the island; indeed, only about 10 percent receive some higher education. Senior high graduation is still an important educational achievement, with many young people, especially girls, getting along with less. But the ladder from kindergarten to doctorate is well known as a clear-cut, honorable, highly prestigious road to security and comparative wealth. People often contrast the harsh physical conditions of manual labor, or the necessary but "crooked" trickiness of running one's own small business, with the apparent simplicity and dignity of moving from grade to grade in an academic and then a bureaucratic hierarchy. Except for some built-in handicaps for more rural Taiwanese, the educational process now operates with admirable fairness in Taiwan. Those who fail to go far in it can hope that hard work and innate talent will carry their children or younger siblings a little farther than they themselves were able to go.

Schooling in Taiwan also develops a strong sense of the value of membership in a group (Wilson 1970), a cultural pattern of great significance in Chinese society. Although children enter school with something of this sense from their experience of family life, the schools expand the students' identification by constantly reminding them of their responsibilities to their classmates, their school, their society, and their country-which includes mainland China. Practice starts with the smallest entity, the class, which elects a leader, undertakes projects, and is collectively rewarded or punished for the behavior of any of its members. Once, when I scolded some members of a college English-language class for their poor preparation, the class head came up to me, white and trembling, to apologize on behalf of the seventy-odd students and to ask what punishment I intended for the class. (He looked mightily relieved when I told him only to get the slackers to do their homework, which he did.)

The emphasis on group unity is an important element in Chinese society, but it contrasts sharply with the devil-take-the-hindmost attitude that Taiwan's economic life fosters, and that many working-class folk I know express. Chinese educators appear to believe that such group-con- 
sciousness has to be rigorously trained into children and that it is not, as Americans often assume, a cultural attribute that Chinese youngsters absorb automatically from their surroundings.

One question that is rarely asked of an educational system is, "What do people actually learn from it?" Schools in Taiwan strive not simply to impart literacy, numeracy, and technical information, but also to mold disciplined and group-oriented characters and to create a nationalistic world view. Although the success of this attempt would be very difficult to measure, it has a powerful effect. The Japanese educational system had much the same general influence (minus the sinocentrism) on an earlier generation as Nationalist education does at present.

People who have spent many years being taught an elite view of what it means culturally to be Chinese, who have learned to accept the discipline of a hierarchically structured school system, and who have taken to heart the Confucian moral values of filial piety and loyalty differ subtly from those with minimal formal education. People who have been working class all their lives-unlike Mrs. Lim and Mr. Kho-have not been as thoroughly instructed by the state in what their cultural identity should be. To me, they seem more open to new ideas (Taiwanese working-class entrepreneurial skill attests to this), more likely to break with custom to follow their own interests, and more unconstrained in their personal relationships than long-educated Chinese. Such openness, individualism, and unconstraint are precisely the characteristics that formal education aims to replace with conformity, group orientation, and tight emotional control. Unless education through high school or college becomes universal, which is unlikely to happen, we can expect a persistence of this difference in personal style between working-class people and Taiwan's elite.

Education has made upward social mobility a possibility in Chinese society for a very long time. For large numbers of people actually to achieve such mobility, however, requires that the economy expand, as it did slowly in the late Qing, rapidly under the Japanese, and explosively since the sixties. Taiwan's people have reason for their strong faith in education; as long as economic expansion continues, the faith in study that engenders sacrifices by parents like Mrs. Zhang, and hard work by children like Lim Fumiko, will be rewarded for a significant part of the population.

\section{Lim Fumiko: Japanese Girl, Chinese Woman}

Lim Fumiko is a Taiwanese woman in her mid-fifties who remembers the Japanese period vividly, and still quietly mourns its passing. Under the 


\section{Chinese Working-Class Lives}

Japanese, Mrs. Lim was one of the rare, well-educated Taiwanese womena graduate of a normal school and a schoolteacher herself. The strong code of submissiveness expected of Japanized women reinforced Chinese ideals so strongly that, after graduation, she meekly married her adopted brother and remained as a filial adopted daughter-in-law in the Lim family. Her experience as a simpua (adopted daughter-in-law) is highly atypical, however. The Lims treated her well, and she retained strong ties to her birth parents until their deaths. Unlike the marriages of many simpua, hers has been a fairly successful one, resulting in a large family of sons and daughters-none of whom was given away in adoption. Mrs. Lim now keeps a small shop and offers us a typical example of the movement of the Japanized Taiwan intelligentsia into small business enterprises after the Nationalist takeover. Such people continue to flavor working-class Taiwanese life with deep respect and admiration for Japan's culture and achievements, and with a sense of having lost membership in a progressive and respected nation only by historical accident.

Mrs. Lim, surely a beauty in her youth, is still beautiful, still graceful, slender, and unlined. In a street where many women her age are plump and careless about daily dress, Mrs. Lim's appearance is all disciplined femininity. Her taste, formed in more prosperous circumstances, is out of keeping with that of her neighbors, though there are richer Taiwanese neighborhoods where her Japanese-adapted Western style is the usual mode. Her way with the give-and-take of verbal etiquette is refined as well, the constant small courtesies of Chinese social relations flowing easily and naturally-delicately flattering to her listener and subtly displaying her skills in politesse.

Her high standards leave their mark, however, only on her own person. Her husband and children have no trace of Mrs. Lim's nicety. They dress, speak, and live like their neighbors: not badly, but with no grace. The difficulty of the struggle for cleanliness and order showed especially in their former house, where nearly forty people (and a shop!) shared less than $\mathbf{2 5 0}$ square meters of space, three taps of cold water, and a constant in-draft of diesel smoke from the eight-lane highway on its doorstep. The rebuilt house the family has occupied since 1980 suits her better, carrying some imprint of her tasteful choices.

She sat with me to reminisce about her life in her house-front shop where she helps run a fruit-and-ice parlor. Such shops are common in Taibei City, selling chilled slices and chunks of semitropical Taiwan's luscious fruitspineapple, mango, watermelon, and papaya-drinks made of pureed fruit, sugar, milk and ice, and dishes of shaved ice topped with sweet bean sauce. In the short but raw winters when these cooling dishes are thought un- 
healthy, Mrs. Lim sells hot sweet bean and millet soups instead. Her clientele consists mostly of undergraduates from the nearby university and uniformed middle school students who drop in between legs of their bus journeys home-impersonal spenders of small sums who require little attention or service beyond the preparation and dishing out of the desired treat. Mrs. Lim can tend the customers and still give most of her attention to visitors, her husband, and her children, or to the large color television set on the wall.

As the family uses the shop for its living room, there is usually a Lim son or daughter about, watching a program, giving a hand at busy times or just loafing. Except on very hot nights, there is little business in the later evenings, so the Lims have the room to themselves at the end of the day. Up and down the street, all over the city, indeed, throughout the island, half the people live in households in which some of the family's income comes from work done in their homes, and the separation between "work" and "home life" that most Americans take for granted never emerges.

Mrs. Lim is a good neighbor, meticulously responding to the births and deaths of nearby acquaintances with small but appropriate gifts of money in red envelopes for happy events, or in white ones for bereavements. She has not sought out friendships among them, however, for, disliking gossip, she has always preferred to mind her own affairs. As the oldest neighboring families slowly move away from the street, she makes less effort to keep track of the other households' doings.

A wish to get on with and to be thought well of by their more established neighbors used to oblige the Lims to participate in three community religious festivals each year. Each household contributes money for opera performances and protective rituals and invites dozens of guests to dinner. Mingling with the crowds of soon-tipsy guests, gorging on the lavish feasts, and following the noisy, colorful operas used to be nearly the only entertainments for the people of this frugal, hard-working community-before television.

Mrs. Lim has never really approved of these celebrations. They cost too much and, she privately believes, are based on mere superstition. She is an educated woman, not interested in the gods, ghosts, and spirit mediums of popular Taiwanese religion. But because everyone expected it, and her mother-in-law insisted, Mrs. Lim shopped and cooked and served and cleaned up every year for forty or fifty eager revelers-a modest number, but respectable. Now, with her mother-in-law too ill to supervise her, she no longer does so. The family contributes money for the public festivities, has an especially good meal for themselves and their married-out daughters in honor of the occasion, and lets it go at that. 


\section{Chinese Working-Class Lives}

By contrast, she tends to the ancestral tablets of ascending generations of Lims diligently, the scent of her daily incense to them curling up the stairs, alerting the whole house that her dinner is prepared and her filiality is perfect. The handsome, heavy altar table of carved black wood on which the tablets stand is the focal point of the neat new formal living room upstairs, as it was in the old house. When Mother-in-Law Lim joins those ancestors after death, she too will be remembered by her filial daughter-in-law through the prayers and offerings that memorialize the unrepayable debt of having received life, or at least the property to maintain it, from one's seniors. Even someone who disbelieves in spirits, as Mrs. Lim probably does, honors such a debt, which has nothing necessarily to do with the supernatural.

In a way that derives from her heavily Japanized girlhood as much as from Chinese ideals for women, Mrs. Lim has lived a life of dependent service to others. Now, in her mature years when most Taiwanese women have fought for and won control of their homes, she still looks about for guidance in managing her family. That she takes charge as much as she does seems due more to her husband's timid incompetence and her mother-in-law's recent senescence than to any taste for power. Uninterested in pilgrimages, too old for her impossible girlhood dreams, she is satisfied, though not content, with her own hearth.

I was born on Eternal Spring Street in 1925, in a family of four sisters but no brothers, and was adopted into the Lim family as a baby. Both my birth family and the Lim family took care of me as I grew up. My mother's family, surnamed Ong, had prospered with a comfortable big house in Eternal Spring Street, and nine more which they rented out. My grandparents didn't have any children, so they adopted my birth mother and father, who married after they grew up. My Ong grandparents could afford to give both my parents a good Japanese education, permitting them to study beyond high school in a teachers' training school. After graduation, my parents taught in primary school.

At that time, when Japan governed Taiwan, richer people were very interested in getting a Japanese education and in Japanese ways. My father even visited Japan once, with his high-school class, although Mother never went. So our family's customs were a mixture of Taiwanese and Japanese ones. Our house was Chinese, as was the furniture in most rooms, but our bedrooms were like Japanese ones, with tatami mats and quilts to sleep on, not bedsteads. We still sleep this way in our family, as it suits the hot climate better. Japanese household arrangements are very clean. My parents wore Japanese clothes to work, though they didn't wear them the rest of the time. I used to wear kimono at New Year. We ate Chinese food, but 


\section{Education}

my father learned to eat raw fish, sashimi, in the Japanese way as a delicacy. We never had it at home and I have never learned to like it.

In my parents' household, and later in my adoptive family, we venerated the ancestors much as we do now. Grandmother made food offerings on the first and fifteenth day of the lunar month, celebrated ancestors' death days with special foods, and put out tea and incense on ordinary days. There are some other special days during the year when ancestors are particularly remembered, too. In addition, by order of the Japanese government, we worshipped the founding god of Japan. This was just a piece of wood with the god's name on it which every household had to have. The Japanese used to have sanitary inspections of all houses, so they could check on things like that. We burned it ${ }^{1}$ after Retrocession.

My school naturally had only Japanese holidays. Before Retrocession, Father and Mother used to read Japanese newspapers; there weren't any Chinese ones. At home and at school we spoke only Japanese. I had close relations with Japanese fellow students and later spoke Japanese with my colleagues at work, so it was my mother tongue. I learned Taiwanese too, of course, from my surroundings, but I didn't begin to learn the Chinese national language until after Retrocession. My adoptive family, the Lims, were not as Japanese-influenced. They spoke Taiwanese at home, and the old people didn't wear Japanese clothes.

Father stopped teaching and went to the mainland, to Hangzhou City, for a while, where he went into business trying to make his fortune, when I was thirteen. He came back because of bad health. He went to the Taiwan University Hospital to recover, then went back to Hangzhou when I was sixteen. He never came back and probably died there. Mother retired from teaching at fifty.

As Mother had to work, my two elder sisters were brought up by wetnurses till they were six or seven years old. Grandmother said, "If anybody wants these two, then we'll give them away," because they were always crying. Mother couldn't spare the time to take care of me, and heard from my relatives that some old lady wanted a girl. I was brought to her when I was fifty days old. My adoptive father and mother had had seven daughters, several of whom were adopted out. She finally adopted a three-year-old boy to care for her and her husband in their old age. I was adopted to be his wife, so I am an "adopted daughter-in-law." My father-in-law mined coal, going to the mine twice a day and delivering it to the professors at National Taiwan University, down the road. It was a hard job, but the money wasn't bad. Though he had seven daughters, there were no sons to help him.

My husband was one of four sons born to a family, related to mine, that

1. A respectful way of disposing of ritual objects. 


\section{Chinese Working-Class Lives}

lives across the river. His father died of a very expensive illness when he was a baby, and all his money was spent for hospital bills. Because they needed money and had many sons, his family allowed my husband to be adopted when he was about three years old. He was adopted about the same time I was and is three or four years older than I am. His life in this family has been different from mine. The old lady breast-fed me just like her own daughter, but because of his age she didn't nurse him, so he was never as dear to her as I have been. Nevertheless, he is still very filial to his adopted mother, very nice to her. The old lady has lived here for eighty years; she was adopted, too.

Both families liked me very much. Over here, in my adopted family, they gave me lots of pocket money, gave me lots of good things to eat, and didn't make me do any housework. They treated me even better than their own daughters because they wanted me to stay to serve them. I really had a comfortable childhood; in my mother's family, I was treated like a guest. If I wanted money, they gave it to me. It was really nice at Mother's. I got along very well with my classmates, and teachers, too. I was happy when I was young. My adopted sisters didn't treat me badly. The eldest two stayed in the family, but the others were all given away while they were small.

We had no toys, although we played cards during the New Year. Mother was strict about our studying, insisting we really use all our energy for it, as otherwise we'd never pass the exams. We wanted to play, but she wouldn't let us. In those days, there was a little stream (which is now covered by buildings) where we would go to play and to pick fruit. The university has built over that now. We went to the Xindian River sometimes, too, to play hide-and-seek. Once, just after entering first grade, I came home almost an hour late because I was playing. So they beat me. After being beaten once, I knew it was not a good idea to worry people.

Because the distance to a good school from Mother's house was shorter, I lived there during my elementary education and went to my mother-inlaw's on Saturdays and Sundays. After sixth grade, Mother suggested that I go further in school, but my mother-in-law disagreed; her own daughters had not gone to middle school. Her eldest daughter's husband and my mother pointed out I always did well in school, so they let me try. If I couldn't pass the exam, then I wouldn't go on. My teachers really helped me, and Mother coached me too. The examination was harder than university entrance examinations are these days, and the quota for us Taiwanese was small.

Taipei only had three upper-level schools. The first and second were for Japanese, and in our school, only half were Taiwanese. Students from the whole province tried to get into that school. I really worked, and I passed 


\section{Education}

the entrance exam. The old lady paid my tuition, and my mother's family paid the rest of the school expenses. While I was in school, I continued to live in my mother's family.

We were forbidden to speak Taiwanese in school. We read Japanese, and that's what the teacher spoke. Even at the beginning, we couldn't use Taiwanese in school; the teachers weren't Taiwanese and didn't speak Taiwanese. It wasn't a case of speaking a little Taiwanese together with a little Japanese. From the beginning, we just slowly learned, and in a few months we could understand, and finally we were able to use it. Although I hadn't been to kindergarten, my mother's family all spoke Japanese, and so I learned quicker than most.

There were sixty students in class, and later about seventy. We went to school at 7:30 in the morning, finished at 4:00 in the afternoon. The fifth and sixth grades had to stay after class to prepare for the examinations. The school had to turn the lights on in the classroom so we could see in the evenings. We went home at dinnertime. This was a four-year girls' middle school-there was no division between junior and senior middle school then.

Because I only studied at that time, I wasn't very good at housework. Mother-in-law was good to me, and didn't give me any to do. Her daughters did it. She just wanted me to study hard.

After four years of middle school, I was graduated at eighteen. I didn't marry immediately but went to normal school for half a year. I had a classmate who wanted to teach, so the two of us went to study at normal school. It wasn't necessary to take an exam-if you'd graduated from middle school, you could enter. I then took a qualification examination to be an elementary-school teacher. I went to Jingmei elementary school to teach because the principal there was my mother's former colleague, and stayed for six years. I liked teaching because I like children-I'm good with them. Some teachers seem to like to get angry and hit children, but I don't. I was very popular in that school.

At that time, my beginning salary was thirty-eight yen, enough to support one person. It wouldn't be enough to support a wife on, but most teachers were female, because of the war. The men went as soldiers, leaving only a few older men teachers, and the rest, women.

Taiwan was returned to China when I was twenty. Because I couldn't speak Mandarin, I thought I would have to retire. However, the principal said we should study Mandarin as the students were doing, so we started. The school got teachers and we went to night school to learn the national Chinese language. At the same time, we kept on teaching. They said we could teach if we learned the national language. I wasn't afraid of losing my 


\section{Chinese Working-Class Lives}

job, because nobody spoke the national language, and it would have been impossible to fire all of us. The whole island was Taiwanese, and nobody could speak the national language. I became quite fluent in it. If my daughter had not become seriously ill when she was about two, so that I had to quit work to take care of her, I might have worked right on till retirement.

Schools didn't stop because of Retrocession, and the men who had gone to war came back to teach again. There wasn't much change in my school at that time. However school became disorderly because of too much freedom; students didn't show as much respect to teachers as they had. After Retrocession, people talked rather wildly about freedom, for some believed that we would now govern ourselves. School became much less orderly, as students rebelled against the strict Japanese ways. Students didn't have any formal meetings to discuss the new change; they just talked among themselves. This went on for over a year, then it slowly settled down. I still have this feeling that present-day students think that teaching is just like any other occupation. To be a teacher was a very special responsibility then.

Our Japanese teachers had to go back to Japan, and that was sad. I remember the day when the principal heard on the radio that Japan had surrendered. He burst out crying. He felt terrible for a month. I had had a Japanese education, so I didn't know what to do; I was as sad as the Japanese. Gradually, anyway, I came to feel that everyone is Chinese, and now, everything is better than in the Japanese period.

Right after Japanese rule ceased, we were still paid - that didn't stopand my salary was much higher than others' because I had passed the qualification examination. At that time, many teachers' salaries were very low.

In general, at that time Taiwan's economy was not at all good. The value of money saved in banks during the Japanese period dwindled to nothing. My husband and I didn't have any bank savings, because we had just begun to work. But I had been buying insurance during the Japanese period. At school, every month you had to buy some. It wasn't much, but we lost it. Mother-in-law lost a great deal, however. She had money in the bank, but didn't buy houses or land or trade with it, she just saved it. After a while, with the continuing inflation, the money was useless.

At that time many goods, such as medicine, were unavailable. My eldest daughter's serious illness required so much money that in one week I spent three months' pay on medicine. Penicillin was expensive but she needed it. Thanks to my husband's business, we got through it. What we spent on her could have bought three houses, so she is now very filial, and gives me big red envelopes at New Year. 


\section{Education}

I was married when I was nearly twenty years old, on December 28, 1944, and had my first daughter when I was nearly twenty-two. After one month, my husband went into the Imperial Japanese Army. He served about a year, always on this island, stationed on the east coast and several other places, but he never had to fight. He came home in 1946. If it had not been the end of the war, he would have been sent abroad. That was a terrible time. When my husband came home, he had no job, so he went to work with his brother who lived with their real mother in Jilong Harbor. I had already left my job, so I went with him. During the six or seven years we lived there, I didn't work, only took care of the children, and began to learn cooking and housework.

My husband was an accounting clerk at Jilong Harbor. For a while this wasn't a bad job. The pay was good, and people made extra money smuggling in foreign goods. But when the place he worked became part of the official harbor affairs organization, the pay and other opportunities became much less.

We began to think of moving because of the low salary but also because we were getting very tired of living in Jilong. The weather there is simply terrible: it rains constantly, and the wind blows. Because of this my bones hurt, I was always cold, and I wanted to go back to Taibei. At first we lived by ourselves over by the university, but when Father-in-law died and Mother-in-law began to fail in 1966, we moved in here with her.

It wasn't easy for my husband to find a job, however. It was around 1951, when conditions were just dreadful. My husband was educated in a private high school, but his education was not the best. He has poor health, so he can't do heavy work, and he has no head for business. He was best at office work. All he could get then was a clerical job in an iron factory where he was introduced by my sister's husband. He worked there until about ten years ago, then changed to his present job.

He works now in the packing department of an export clothing factory in the town across the river from where he was born. He's not an office worker anymore, just a manual worker. He earns NT\$10,000 (U.S.\$250) each month, more if there is overtime. He also gets one month's pay as a bonus at New Year. There are no fringe benefits, really. His labor insurance only covers himself, so our family must pay everything for our medical expenses. Taiwan's prosperity hasn't done much for my family.

You can see that with our large family, it hasn't been easy. In recent years, living with Mother-in-law, with the children nearly all grown, you'd think it would get better. My mother-in-law is rich, but she's also very close with her money. And right now, for example, none of the grown children still at home has a full-time job! It has often been very difficult to manage 


\section{Chinese Working-Class Lives}

with all our children. A few years ago, when Taiwan's economy turned bad again for a while, we really suffered. Only my husband had work, so I was forced to take on the job of caring for a one-year-old girl whose mother worked in a bank. She paid me NT\$1,000 (U.S.\$25) each month. Lulu came to us Monday morning and stayed till noon on Saturday. She was very cute, but just at the worst age. She wanted to walk, but a baby that age can pull down a gas burner, or fall into the toilet, or have some other accident. The old house was so dirty and the traffic so near the door that I never dared to put her down. I had to carry her on my back all the time as I did the housework for this large family. I was always tired that year.

We have eight children. At first, I had four daughters in succession, and finally two boys. I decided to have an operation so I would stop having children, but my mother-in-law refused to allow this. She thought my health was too poor to stand an operation, so I had two more daughters. Eight altogether. Having so many children has not been good for their education or my health. I've had bad luck. Formerly, women had to have so many children. I agree with today's family-planning policy; two are just enough. I wanted to abort my eighth child, but the doctor refused because the operation was dangerous. Since I already had seven, another wouldn't make much difference, he thought. I didn't have the strength to push out the eighth baby. It took several hours. I was thirty-nine then so I decided not to give birth anymore. My husband began to sleep in one bedroom with the boys and I slept in another with my two younger girls.

My eldest daughter is the one who's caused us the most difficulty, even though she's really a good girl, always helping me. When she was nineteen, she liked to dance, and she met a young man at a party. They decided they wanted to marry. Well, there were problems. For one thing, the young man was a Mainlander whom we didn't know. The old lady naturally preferred her to marry someone more familiar. But-and this is much worse-our family had already planned a marriage for her, which my daughter had never objected to.

The man we wanted her to marry is our Mr. Su, who lives with us and manages the fruit-and-ice shop. Mr. Su has a bad fate, surely. He was a soldier from north China who came here in 1949 with the government forces, but he was demobilized after a few years because his health was so poor. He says he nearly died from years of bad army food and from getting almost no food after the army came to Taiwan. When they demobilized him, they just turned him loose with not enough to live on, and no job. $\mathrm{He}$ was living in a little room across the street twenty years ago when we got to know him. He rented a room in our house and began to eat meals with us. He was a taxi driver then. At one time, when my husband was earning only 
a few hundred New Taiwan dollars a month, we still gave it all to Mother-inlaw, who gave us NT $\$ 30$ (U.S. \$0.75) a day for food. It was impossible to feed the family on that. Mr. Su gave us NT\$40 (U.S.\$1) a day to eat with us, so we can say that he helped to rear our children. I told the children to be nice to him, and he seemed more and more like one of the family.

He had never been married and naturally wanted to have his own family. He asked us about our daughter when she was still quite young. They seemed to get along well, and we knew he had a good character, so we began to treat him as a kind of son-in-law. He opened an electrical appliance repair shop in our house. My mother-in-law was very pleased that my daughter would be marrying him so she could remain at home and help in the business.

Then my daughter met her future husband. She argued that Mr. Su was too old for her-fifteen years older. Besides, she wanted the other one. The old lady was very angry, refusing to do anything for them. So they went to court and got married in a civil ceremony and now Mother-in-law won't let my daughter in the house. It's been five or six years, and she still won't have her back. She's very stubborn.

The old lady took her anger out on me. Though she had always been so good to me, she now scolds me constantly. I was wretched when this all happened and cried a great deal. This was the biggest conflict between the generations that we have had.

I was disappointed at my daughter's decision, but I decided not to interfere. I remember so well the day I was to be married. Suddenly, I felt I just could not go through with it. I wanted to die. My husband and I have never been close. My sisters came to persuade me that it was my duty to marry him. Everything was arranged by all of our relatives; it would be very improper for me to oppose their will. I married, but could never force my daughter to marry against her wishes. Both my older daughters have chosen husbands for themselves.

That marriage turned out well. My daughter's parents-in-law and husband are good to her. Her father-in-law is a general who works in a government bureau, her mother-in-law used to be a teacher, like me. Though her husband had been a bit of a playboy who liked to drink and dance, after they married, he went to university. He became a good man and a good husband for her. Her parents-in-law have said to me, "We didn't bring our son up properly; now your daughter is doing it for us." It's my daughter's good destiny.

I really pity $\mathrm{Mr}$. Su, though. He can't bear to be near my daughter now because he loved her deeply. It is very sad for these old soldiers with no family and friends to help them. He should keep trying to get a wife. 


\section{Chinese Working-Class Lives}

Though he has been introduced to some prospects, they've all turned him down. He sometimes talks of going back to the mainland to look for his brothers. They were educated people; one of his brothers became a university professor. There's no political motive, he just wanted to find his family. But my daughter warned him, "If you go, you won't be able to get back." He still lives with us, running the fruit-and-ice store, and helped a great deal when we were having the house rebuilt last year.

Our second daughter married years ago and has two children. I don't worry about her. The boys, now twenty-one and twenty-two, were not good students, never wanting to study. Each of them has done his two years of military service in the army, but neither has a job yet. The older may be working in a munitions factory soon. Though that is not much of a job, it may be the best he can do for the present. My husband's brother just last night suggested that if we think the younger boy can learn to make bread, he can find someone whom we can hire to teach him how to bake. It's not a bad idea, selling bread from our new shop. He is willing to learn. It's hard work, so it will have to be up to him. I have never pushed and forced my children to do things.

My third and fourth daughters weren't good students, but they are very dutiful. They have had different jobs since graduation from senior high school, always part-time office work that pays each of them only five or six thousand a month. They are very shy girls, so they still are not thinking of marriage, although they are in their late twenties. I worry about that. They should marry and get established before the boys marry. Already, we have found a young woman who works at my husband's factory who might suit our oldest son well. We'll have to wait and see about that. When the boys are earning money and our business is prosperous-that will be time enough.

Of all my relatives, I have the greatest obligation to my adopted motherin-law. Her daughters have all moved away. My husband's original family has his brother to rely on, and my mother died a few years ago. So old Mrs. Lim needs me most. She raised me so that I would take care of her when she became old. Now she's bedridden, and often can't understand anything, but my husband and I try to take care of her, to cherish her.

My mother-in-law has never had good luck or good judgment with money. In the early 1960s she bought some land, and it was taken by the government to build a sports field for the university. There was compensation, but not what the land was worth. We didn't get into the trouble of land reform as did people who owned substantial land; we only own this house, while another is in her daughter's name. In recent years, the old lady put all 


\section{Education}

her money out at interest, some in rotating credit associations, but mostly to individuals for interest. She has had some big losses-a couple of people just absconded. We lost enough to buy another house like this one.

The Lims have lived in a house on this spot for five generations. This little neighborhood, Prosperity Settlement, was always a small commercial district, not a farming village. The houses were built of brick along the road, as they are now, as long as I have known the place. The Japanese built a railroad right behind our house in the 1920s, but it was taken out and the main motor road that runs past the front of the house was widened and concrete-surfaced after the Nationalist government came here. It was named Roosevelt Road then, to honor the American president who helped Taiwan to reconstruct after the war. We lost a small amount of land at the front of our house when the road was widened, and had to rebuild the front part of the house. Roosevelt Road was widened again in 1971, but it didn't affect our house, except to make this a busier commercial district. It's been good for business.

To make up for what we lost in the front, we extended our house backward over the old railroad bed. That was not exactly legal because the land is the government's. But there has never been any trouble about it. Every house in the Prosperity Settlement did the same thing. We also raised the house higher, so that we had three stories. The upper floors were rented out-two families to each floor, each with two rooms, sharing kitchen and bathroom. We put running water up to each floor so it was very convenient, even though when a downstairs family was using the water, the upstairs family didn't get any.

My mother-in-law earned quite a bit of money from the rentals, which we needed, but we also began to feel very crowded. Behind the appliance shop was the bedroom that my husband shared with our sons, then one for me and my middle two daughters. Mother-in-law slept in a small room out behind the kitchen. Sometimes the two little girls slept with her, sometimes with $\mathrm{Mr}$. Su upstairs. The rooms are not large, and when the girls began to have more clothes, we felt very cramped. Sometimes our tenants were not very clean or had fights in their families. There were always more than thirty people in this house.

Three years ago, we decided to rebuild the house completely. It was a good time to do it because the Taibei City government was altering Roosevelt Road again to build a bridge across the river. Although the changes would not affect us directly, the value of the property would increase a lot, and so would the taxes. The rents we got were not enough, we thought. Also, many of our neighbors would be directly affected by the road widen- 


\section{Chinese Working-Class Lives}

ing and started to tear down their small old brick houses to replace them with modern four- and five-story ones. We thought it would look bad if we did not do the same. My mother-in-law approved, because she thought we could earn a lot of money from rents.

It is easy to get building work done in Prosperity Settlement, where many men are construction workers. They know the trustworthy contractors, and we cooperated with our neighbors in a unified design. It was a mess for a while, but we are very satisfied with the house now. Mr. Su's and my fruit-and-ice shop and our kitchen are downstairs, along with one bedroom for Mother-in-law. The rest of us have larger bedrooms on the second floor, and the bathrooms are modern ones with Japanese-style flush toilets. ${ }^{2}$ It's much cleaner. We rent out the third floor for four thousand and hope to rent the fourth very quickly. The whole thing cost NT $\$ 180,000$ (U.S. $\$ 4,500$ ), of which we had to borrow NT\$80,000 (U.S.\$2,000) through a rotating credit club.

Recently; I've been thinking about the Japanese times again, because I saw two Japanese films at the Golden Horse Film Festival last week. It was the first time I'd seen Japanese life in many years, and I felt very strange. When I was a child, I didn't like to go to movies because the theaters were crowded and smelly. But now Japanese movies seem more artistic and moving than Chinese ones. Most present-day Chinese films are just made to make money, so I rarely go. I used to go to see Japanese ones, which were shown up to about fifteen years ago. Then they were banned, so I hadn't seen one until this foreign film festival. My older son stood in line for about five hours to get me the tickets! They were very popular.

My whole early life was lived in the Japanese period, which is why I thought of myself as Japanese and never considered that I was Chinese. At Retrocession, my feelings were strange, I was puzzled. What would things be like? What were we going to $b e$ ? The principal of the school I worked in cried for a whole month and didn't speak to anyone during that time. Later, we became Chinese gradually, and now I feel it's good to be a Taiwanese, though the Japanese did not treat us badly.

Because I get together with my old classmates twice a year for reunion dinners, I still can speak Japanese quite well. Consequently, some of the neighbors have asked me to teach a class to their daughters. Because there are many Japanese tourists and businessmen in Taipei, many girls would like to learn Japanese to help them get a job. But I have many responsibilities at home, so I can't go out to work. It is a long time since I was a teacher. I'm too old to start something new.

2. "Squat" toilets, with the bowl set into the floor. 


\section{Education}

\section{Postscript, 1985}

When I dropped in on them unexpectedly on the last day of 1985 during a brief visit to Taiwan, the Lims hospitably insisted I stay for dinner. During the delicious Taiwan-style hotpot meal, I caught up on family news that our infrequent correspondence had only incompletely described.

Mother-in-law Lim died three years ago, and Lim Fumiko herself has become a mother-in-law to her older son's wife. The son, his wife, and little boy live upstairs, as do the Lims' third and fourth daughters, now married. Number Four, A Bi, has a three-year-old daughter with all her mother's charm but none of her shyness. Number Three, A Gu, is as silent as ever, but glows like a camellia with her first pregnancy. Daughter Number Eight studies hard at college, hoping to go to the United States for graduate school. The other son and daughter work full-time, looking forward to marriage.

The house is full of family, but there are renters, too. Mr. Su, who now corresponds, cautiously, with his professor brother on the mainland, shares a room with an Aborigine boy who needs to live in town to attend high school. The Lims patronize this ethnic outsider a little, but kindly, as they treated me when I too was a cultural alien in their home.

Mrs. Lim has aged with the strain of caring for her adopted mother in her last years of illness. Always demanding, she became nearly unbearably fractious toward the end. The struggle to keep the old lady clean, to tempt her appetite, and to massage aching old bones into comfort shows on her face; lovely Lim Fumiko is now an old lady herself.

But her ideas have not changed, as I gathered from hearing her daughters discuss the shop's business. Mrs. Lim and Mr. Su have expanded into simple noodle dishes and other fast-food take-out meals. Although there are plenty of customers, the daughters complain, the shop doesn't earn much because Mrs. Lim insists on the same high standards of raw materials and preparation for these cheap meals as she does for her own family.

"I couldn't cheat people by giving them bad food!" says Lim Fumiko.

"How will we ever get ahead that way! Business is business!" says A Bi.

But this disagreement, like A Gu's momentary grumpiness toward her sister over the baby's plasticine mess on the table top, is not disagreeable. Theirs is a loving home, where a strong sense of duty helps keep people doing right by each other when affection fails, as it sometimes must. Mrs. Lim's principles, drawn from the best of her Chinese and Japanese heritages, live on in her filial children, giving them both a strong family bond and a sense of decency and kindliness that reaches beyond the kinship circle. 